\title{
Linguistic and Cultural Problems in Translation
}

\author{
Tiara Ridha Imami ${ }^{*}$, Fatchul Mu'in², Nasrullah ${ }^{3}$ \\ ${ }^{1,2,3}$ Universitas Lambung Mangkurat \\ *Corresponding author.Email:1710117120021@mhs.ulm.ac.id,
}

\begin{abstract}
Cultural problems in translation arise due to differences between the two languages in expressing identity and lifestyle. Translators will find it difficult to translate abstract or concrete concepts in the source language/culture (SL/C), completely unknown in the target language/culture (TL/C). This paper addresses two problems namely linguistic problems and cultural problems. Linguistic problems include lexical, morphological, syntactical, and semantic problems. The cultural problems include terms in ecology, terms related to cultural objects,terms related to life like society, work and leisure, and terms related to organization, customs, activities, procedures, and concepts. The data was gathered from J.R.R. Tolkien's novel "The Hobbit or There and Back Again" and its Indonesian translation "Hobit atau Pergi dan Kembali" which is translated by A. Adiwiyoto. The findings show that there are many adjustments as well as the phenomenon of equivalence between the two languages. The meaning that the author wants to convey, the structure of words and sentences, point of view, rhyme, wordplay, context, socio-cultural, and geographical conditions are things that affect the form of translation presented. These findings suggest that the use of good approaches, methods, and procedures will result inan acceptable translation and convey the meaning of the SL without having to sacrifice many things.
\end{abstract}

Keywords: Linguistic and Cultural Problems, Translation, Source Language, Target Language, Approaches, Methods, Techniques of Translation

\section{INTRODUCTION}

Generally, language is believed to function as an important instrument for expressing ethnic culture: beliefs, customs, rituals, and behaviors, which constitute the identity of a particular ethnic culture. This can be seen as a manifestation of action for most humans, that language is closely related to human essence and belongs to certain cultural groups. Furthermore, this can be seen as a social phenomenon in human society that establishes a set of rules, norms, and socio-cultural values, conventions, which are used as guidelines for working together and interacting with each other and maintained and passed down from generation to generation. Meanwhile, Mu'in [1] stated a language is an element of culture; in certain circumstances, a culture is expressed through a language.

'Die, 'live, 'star,' and 'swim' which are denotatively the same meanings in Indonesian, namely: 'mati,' hidup, 
'bintang,' 'berenang' and even almost all the artifacts that are everywhere like 'mirror." (meaning, cermin) and 'table' (meaning, meja) are universal words - there are usually no translation problems with these words. Words or phrases such as "madrone" (a species, pohon), "pelicans" (a species, burung), "crib" (name of object), "Ivory Coast" (name of country), and "White House" (name of the building) are cultural terms. These cultural words or phrases cannot be translated directly to get accurate, acceptable, and readable translation results.

Language and culture are two things that cannot be separated because culture affects language and language affects culture. This makes the language in one area different from another. The difference in the cultural background of each language is a unique phenomenon that occurs in society and is a difference that must be respected, not to be disputed. Moreover, it affects many things, including the literary works in each part of the region.

Literature is a work that is timeless and always has its audience. Often, it is the product of the thoughts, experiences, and imaginations of its authors. In addition, the socio-cultural background also affects the literary work. Many literary works were born from various parts of the world, and some are popular in the region and have become internationally popular literary works. This gives rise to the parties' efforts so that the literary work can be read by people outside who may speak a different language from the original language of the literary work. After being translated into foreign languages, literary writings written in various regions of the world reach a new audience [2].

The translation is an attempt to translate words from the source language to the target language. It plays an important role in the spread of information throughout the world, and there is no exception for literary works that are amazing for their audiences. Then, as is well known, language is closely related to culture. Translating a language with more or less cultural factors into a target language with a different culture and background is a challenge in itself. The differences in words and grammar are also very important things to consider in translating something. This is not to mention if the source language text contains the figure of speech and aspects of beauty. Equivalence between the source language and the target language is a must. The meaning that the author wants to convey is still conveyed to the readers even through different languages.

The process of translating from a source language to a target language involves language and cultural considerations. The process of translating from the source language (and its culture) to the target language is known as translation (and its culture). We use the same term "equivalence" in this situation. In other words, there must be "equivalence" (equivalence) between SL and TL in translation. From this, we can say that translators transfer culture, not language. Language is not the main aspect (only the medium) in the translation process but the main aspect is culture, which must be translated. Therefore, full attention in the translation process is on cultural procedures rather than linguistic procedures. Translating is the most challenging job because if the two cultures cannot correlate or give a clear idea about the aspect of the culture in question, it may be meaningless.

The differences in socio-cultural, geographical conditions, and grammar that underlie a language as a medium in a literary work and its translation are interesting. This could be due to the equivalences taken by a translator in translating it from the source language to the target language and the adjustments made to the translation. Moreover, there will be culturally charged or common words in the source language that cannot be found in the source language or are not possible to translate without reducing much meaning of the word. In addition, grammatical differences between the source and target languages will lead to adjustments between words, phrases, clauses, sentences, and even paragraphs.

Based on that problem, the researcher is interested in researching the phenomenon of language and cultural problems that can be found in translated literary works. This can help translators to add insight into literary translation and what problems might be found in translating literary works. Therefore, the researcher conducted a study that aims to find out the linguistic and cultural phenomena that appear in the novel entitled "Hobit atau Pergi dan Kembali" which was translated by A. Adiwiyoto from the novel entitled "The Hobbit or There and Back Again" by J.R.R. Tolkien.

\section{REVIEW OF LITERATURE}

\subsection{Language and Culture}

Humans need language to convey the contents of their thoughts and feelings to something or someone. Language's importance in generating text and expressing meaning is growing, as evidenced by its involvement in global cultural and linguistic growth trends, as well as inter-lingual correlations and interactions [3]. The use of language varies greatly depending on the needs or goals to be achieved. Mu' in [1] stated language is commonly comprehended to enable humans to interact and communicate. The use of the same language with the surrounding community makes an utterance easy to understand while using a different language with the surrounding community will cause "difficulty" in communicating. Therefore it is necessary to understand what language one wants to use in communication and interaction. 
Generally, culture shapes people, and humans shape culture. Culture in society is certainly different from the culture in other societies. Mu'in [1] stated humans are guided by culture in their lives. Furthermore, the differences between a person, a group, a nation, or a country may be seen in a variety of ways, and one of the most distinguishing characteristics is culture [4]. The diversity of the cultures requires each party to respect and understand each other. We cannot comprehend motivation and people's lives, and connect with their interests and concerns without culture [5]. In addition, the relationship between culture, people, and the language used will affect various aspects, one of which is literature which is more or less influenced by the culture in which the author comes from or where the story is told. The discussion will be more interesting if it is about literary works translated into different languages and distinctly different cultures.

\subsection{Translation}

The translation of a literary work is needed to reach readers who have a different language from the language of the original literary work. Newmark [6] stated that it (translation) conveys the meaning of a text in another language following the author's intended; this occurs frequently, but not always. Translation is the cultural interchange of languages as well as the conveyance of information [7]. Translation cannot be done haphazardly, some various methods and procedures can be applied in translating something so that the intent and purpose of the original text can be conveyed even through different languages. Decreasing the gap between two cultures is deemed can be done by translators [8]. Proficiency in mastering two languages and their use is very important for the translators to have. Translators who have the capacity to convey and recreate works of art, as well as a sensitivity to literary language, may translate more creatively [9]. Moreover, [10] has suggested, translation is essentially theoretical, despite the fact that it is a very practical skill.

There are several translation methods, it is separated into two parts of emphasis, one emphasizes the source language, the other emphasizes the target language. There are Word-for-word translation, Literal translation, Faithful translation, and Semantic translation are the methods that stress the SL. Following that, Adaptation, Free translation, Idiomatic translation, and Communicative translation are the methods that highlight the TL [6].

There are also several procedures in translation. The translation procedure is applied to smaller parts of the language and sentences, while the translation method covers the entire text. There are Literal Translation, Transference, Naturalization, Cultural Equivalent, Functional Equivalent, Descriptive Equivalent, Synonymy, Through-translation, Shifts or
Transposition, Modulation, Recognized Translation, Translation Label, Compensation, Component Analysis, Reduction, and Expansion, Paraphrase, Other procedures (Equivalence and Adaptation), Couplet, and Notes, Addition, Glosses [6].

Moreover, translating from one language to another has interesting problems to explore because of the fundamental differences between the two languages as well as their cultural backgrounds. In this regard, within the scope of language problems, there are lexical and morphological problems, syntactic problems, and semantic problems in translation.

In translation, the concept of the "cultural term" or "cultural word" is quite frequent, especially in literary translation [11]. Literary translation is a form of bilingual rewriting of a literary work that includes a variety of processing techniques, ranging from comparative natural language to knowledge processing [12]. In cultural problems, translators classify cultural words in many fields. Mu'in [13] stated the first is a term in ecology. This ecological term relates to geographical features that are free of political or commercial value and can usually be distinguished from other cultural terms. For example the terms flora, fauna, wind, plains, hills, seasons, etc. Both are terms related to cultural objects such as food, clothing, houses and cities, and transportation. Food is the most sensitive and important expression of national culture for many people, for example, sate, coto, sego pecel, and others. Clothing as a cultural term can be in the form of national or traditional costumes such as sarung, yukata, kimono.

\subsection{Previous Study}

There are several previous studies related to linguistic and cultural issues in translation. Satisha [14] has done a study entitled "Linguistic and Cultural Challenges Faced by Translators". It is about the language and cultural problems faced by translators in translating SL to TL which have different languages and cultures. This includes costumes, activities, conversations between people, methods of celebrating celebrations, and traditions. It also offers solutions to these problems.

Another study has been done by [15] entitled "Linguistic and Cultural Issues in Literary Translation". A case study of translating a short tale from Arabic to English is discussed in this article. The study focussed on the translation process and reconstruction, with specific relevance to some of the linguistic and cultural difficulties that arose in the original and how they were addressed in the translation.

The other study have been done by [16] entitled "Linguistic and Cultural Issues in Translating Negation in Literary Texts: A Case Study, Mourning Becomes Electra, by Eugene O'Neill'". It is about analyzing the 
techniques used by Petru Comărnescu and Margareta Sterian in their translation Romanian of "Mourning Becoming Electra." by Eugene O'Neill. This study shows the obstacles of translation and highlights the necessity of cultural understanding while communicating.

In the researcher's research, the researcher will focus on analyzing the phenomenon of linguistic and cultural problems in the Indonesian translation of the novel "The Hobbit or There and Back Again" by J.R.R. Tolkien translated by A. Adiyoto into Indonesian language. The differences between the two languages and their culture make this interesting to discuss. Considering the many factors that affect the result of a translation.

\section{METHODOLOGY}

\subsection{Research Design}

This study uses a qualitative method. The researcher took data from the two novels, grouped them, analyzed them, and concluded the results. data is presented in tables and the form of words. Moreover, the researcher will discuss and analyze the phenomenon of the problems found in the data that has been taken. Creswell [17] stated although quantitative and qualitative methodologies are similar, qualitative approaches incorporate text and picture data, have unique data processing steps, and employ a range of designs.

\subsection{Object of The Research}

The sentences and stanzas in the books were the focus of this study. The data was gathered from J.R.R. Tolkien's novel "The Hobbit or There and Back Again" and its Indonesian translation "Hobit atau Pergi dan Kembali" which is translated by A. Adiwiyoto.

\subsection{Data Collection}

The data sheets are needed as a medium in this study. The tables and the explanations are processed in such a way as to compare and analyze the data. The final data is obtained from the results of the analysis of the data that has been collected.

\subsection{Data Analysis}

The steps taken by the researcher in analyzing the datathat have been collected are as follows:

1. Take a few sentences and stanzas from the novel in each language.

\section{Compare word usage between SL and TL.}

3. Compare the meaning of each line.

4. Analyze and determine the method used by the translator in translating the text through the procedures used.

5. Analyzing linguistic and cultural problems found.

6. Conclude.

\begin{tabular}{|c|c|c|c|c|}
\hline $\begin{array}{l}\text { Sourc } \\
\text { Language }\end{array}$ & $\begin{array}{r}\text { Target } \\
\text { Language }\end{array}$ & $\begin{array}{l}\text { Procedures } \\
\text { ofTranslation }\end{array}$ & $\begin{array}{l}\text { Methods } \\
\text { of } \\
\text { Translation }\end{array}$ & Notes \\
\hline $\begin{array}{l}\text { Blue sky and } \\
\text { never a cloud and } \\
\text { the sun dancing } \\
\text { onthe water. }\end{array}$ & $\begin{array}{l}\text { Langit biru tak } \\
\text { berawan, bayangan } \\
\text { matahari menari- } \\
\text { nari di permukaan } \\
\text { air. }\end{array}$ & $\begin{array}{l}\text { - Equivalent } \\
\text { - Adaptation. }\end{array}$ & $\begin{array}{l}\text { Semantic } \\
\text { translation }\end{array}$ & $\begin{array}{l}\text { The SL sentences contain } \\
\text { aspects of beauty, which are } \\
\text { maintained in the equivalence of } \\
\text { the translation. }\end{array}$ \\
\hline $\begin{array}{l}\text { If you stepped } \\
\text { behind, you found } \\
\text { a low arch in the } \\
\text { side of the } \\
\text { mountain }\end{array}$ & $\begin{array}{l}\text { Di balik batu ada } \\
\text { sebuah celah } \\
\text { sempit di lereng } \\
\text { pegunungan. }\end{array}$ & $\begin{array}{l}\text { - Transposition } \\
\text { - Modulation } \\
\text { - Compensation }\end{array}$ & $\begin{array}{l}\text { Communicat } \\
\text { ive } \\
\text { translation }\end{array}$ & $\begin{array}{l}\text { Some adjustments can be seen } \\
\text { in the translation, such as } \\
\text { changing positions and } \\
\text { compensation from one part of } \\
\text { the sentence to another. }\end{array}$ \\
\hline $\begin{array}{l}\text { P'raps there are } \\
\text { more like him } \\
\text { round about, and } \\
\text { we might make a } \\
\text { pie. }\end{array}$ & $\begin{array}{l}\text { Kali-kali ada } \\
\text { banyak yang } \\
\text { seperti dia di sekitar } \\
\text { sini. Kita bisa bikin } \\
\text { mereka jadi petis. }\end{array}$ & $\begin{array}{l}\text { - Cultural equivalent } \\
\text { - Adaptation }\end{array}$ & Adaptation & $\begin{array}{l}\text { There are the adaptation of the } \\
\text { noun and the form of words here. }\end{array}$ \\
\hline
\end{tabular}




\section{FINDINGS AND DISCUSSION}

\subsection{Finding}

Some several sentences and stanzas have been compiledby the researcher more than the data presented above,

\subsection{Discussion}

SL : Blue sky and never a cloud and the sun

TL $\quad$ : Langit biru tak berawan, bayangan matahari menari-nari di permukaan air

\begin{tabular}{|c|c|c|c|c|}
\hline \begin{tabular}{l}
\multicolumn{1}{c}{ Sourc } \\
e \\
Language
\end{tabular} & $\begin{array}{r}\text { Target } \\
\text { Language }\end{array}$ & $\begin{array}{l}\text { Procedures } \\
\text { ofTranslation }\end{array}$ & $\begin{array}{l}\text { Methods of } \\
\text { Translation }\end{array}$ & Notes \\
\hline He was desperate. & Kini ia nekat & - Equivalent & $\begin{array}{l}\text { Communicative } \\
\text { translation }\end{array}$ & $\begin{array}{l}\text { The translation clearly } \\
\text { can be directly } \\
\text { understood by the TL } \\
\text { reader. }\end{array}$ \\
\hline $\begin{array}{l}\text { Out of the frying- } \\
\text { pan into the fire }\end{array}$ & $\begin{array}{l}\text { Lepas dari mulut } \\
\text { harimau jatuh ke } \\
\text { mulut buaya }\end{array}$ & - Cultural equivalent & $\begin{array}{l}\text { Idiomatic } \\
\text { translation }\end{array}$ & $\begin{array}{l}\text { The idiom from } \mathrm{SL} \text { is } \\
\text { translated into idiom in } \\
\text { TL. If an idiom is } \\
\text { translated literally } \\
\text { without notes, its real } \\
\text { meaning is not } \\
\text { conveyed. }\end{array}$ \\
\hline $\begin{array}{l}\text { A box without } \\
\text { hinges, key, or lid, } \\
\text { Yet golden } \\
\text { treasure inside is } \\
\text { hid, }\end{array}$ & $\begin{array}{l}\text { Ada kotak } \\
\text { tanpa engsel, } \\
\text { tanpa kunci atau } \\
\text { penutup, } \\
\text { Tapi di disi } \\
\text { dalamnya berisi } \\
\text { emas yang hidup. }\end{array}$ & $\begin{array}{ll}\text { - } & \text { Descriptive } \\
\text { - } & \text { Parivalent } \\
\text { - } & \text { Paraphrase }\end{array}$ & $\begin{array}{l}\text { Semantic } \\
\text { translation an } \\
\text { dFree translation. }\end{array}$ & $\begin{array}{l}\text { The adjustment is very } \\
\text { clearly seen in the } \\
\text { second line. }\end{array}$ \\
\hline $\begin{array}{l}\text { Burn, burn tree } \\
\text { and fern! } \\
\text { Shrived and } \\
\text { scorch! } \\
\text { A fizzling torch } \\
\text { To light the night } \\
\text { for our delight, } \\
\text { Ya hey! }\end{array}$ & $\begin{array}{l}\text { Menyala, } \\
\text { menyalalah pohon } \\
\text { dan pakis! } \\
\text { Sementara } \\
\text { Kurcaci meliuk } \\
\text { dan meringis! } \\
\text { Api menyala } \\
\text { berkobar, } \\
\text { Seperti sinar obor } \\
\text { memancar! } \\
\text { Malam pun } \\
\text { menjaditerang, } \\
\text { Dan hati kita pun } \\
\text { girang! } \\
\text { Ya, hei! }\end{array}$ & $\begin{array}{ll}\text { - } & \text { Descriptive } \\
& \text { equivalent } \\
\text { - } & \text { Transposition } \\
\text { - } & \text { Modulation } \\
\text { - } & \text { Compensation } \\
\text { - } & \text { Componential } \\
& \text { analysis }\end{array}$ & $\begin{array}{l}\text { Semantic } \\
\text { translation, } \\
\text { Communicative } \\
\text { translation, } \\
\text { Adaptation, and } \\
\text { Free translation }\end{array}$ & $\begin{array}{l}\text { The adjustment of } \\
\text { sounds and rhymes } \\
\text { between lines creates } \\
\text { an additional } \\
\text { sentenceand } \\
\text { adjustment in the } \\
\text { words themselves. }\end{array}$ \\
\hline
\end{tabular}


The first sentence that will be discussed is "Blue sky and never a cloud and the sun dancing on the water." which is translated into "Langit biru tak berawan, bayangan matahari menari-nari di permukaan air." There is an adjustment of the phrase structure from "Blue sky" to "Langit biru". It also can be seen clearly that this sentence contains an element of beauty and uses personification in it. Simply said, translating literature is difficult because it entails interpreting works' figurative or metaphorical meanings [16]. The beauty aspect of this sentence seems to be preserved in the translation. Newmark [6] defined Semantic translation prioritizes the aesthetic value of the text, i.e., the attractive and natural sound of the SL text, sacrificing 'meaning' when necessary to avoid word-play, assonances, or jars of repetition in the final form. Morover, The use of the word "tak" instead of the word "tidak" in TL shortens the sentence as well as adds to the poetic impression, and the word "bayangan" here which accompanies "matahari" makes its meaning clear even though there is no literal word of "bayangan" in SL. Newmark [6] stated 1) Equivalence, defined as words that take into account the same circumstance in different ways, implies near equality and 2) Adaptation, which is the usage of a recognized equivalent in both circumstances; it is about cultural equality according to Vinay and Darbelnet.

SL : If you stepped behind, you found a low arch in the side of the mountain.

\section{TL : Di balik batu ada sebuah celah sempit di lereng pegunungan.}

Afterward, the sentence "If you stepped behind, you found a low arch in the side of the mountain." which is translated into "Di balik batu ada sebuah celah sempit di lereng pegunungan.". This translation can be easily understood by TL readers. Communicative translation aims to give as much of the source language's contextual meaning as feasible so that the material and language are easily understood and accepted by the audience [6]. The reader's involvement as "you" in TL is lost in SL, and there is a change of point of view here. Modulation was invented by Vinay and Darbelnet to explain 'variety through shifting viewpoints, points of view, and frequently categories of thought [6]. In addition, the core meaning of SL is still conveyed. There is also a pretty noticeable adjustment of scientific and technical terms phenomena that are "a low arch in the side of the mountain" which translates to, "celah sempit di lereng pegunungan". The literal meaning of "low arch" is "lengkungan rendah", but regarding the context, the use of "celah sempit" is still correlated with the meaning contained in the SL. Linguistic and cultural analyses based on diverse (including cultural) verbal complex networks were conducted from many scientific viewpoints and at various degrees of science [3]. Compensation happens when a sound effect, meaning, pragmatic effect, or metaphor is lost in one area of a sentence, it is compensated in another segment, or a neighboring sentence [6]. The translator's knowledge of mountains also gives rise to the words, "di balik batu" at the beginning of the sentence. This is also closely related to the fact that every field of science has its scientific terms. Chen [18] stated, in contrast to nonliterary translation, the difficulty in literary translation is also about understanding the notion of translation and the translator's translation style, rather than just transmitting the primary idea and style of the original author's language. Moreover, the grammatical change from SL to TL can be seen from the simple past tense form of SL into a sentence form in TL. Newmark [6] stated Transposition is a procedure of translation that includes transforming the grammar from the source to the target language.

SL : P'raps there are more like him round about, and we might make a pie.

TL : Kali-kali ada banyak yang seperti dia di sekitar sini. Kita bisa bikin mereka jadi petis.

The next sentence is "P'raps there are more like him round about, and we might make a pie." that is translated into "Kali-kali ada banyak yang seperti dia di sekitar sini. Kita bisa bikin mereka jadi petis". It is visibly seen in this sentence about the phenomenon of socio-cultural linkage with the final result of translation. This sentence seems informal because it is one of the sentences spoken by the Trolls who are said to have bad grammar and words [19] and [20]. The translator is aware of the context of what he is translating. Then, it can be seen, the word "pie" in SL is translated into "petis" to TL which looks more familiar to the ears of TL readers than "pie/pai" itself, even though the two things are completely different. We must remember that translation entails not just giving equal meaning in TL, but also recognizing the values of TL and SL, whether they be linguistic or cultural values [16]. Among the various ways of translation, adaptation is the most 'loose'; it is most commonly employed for plays (poetry and comedy); ideas, storylines, and characters are usually retained; texts are changed, and SL culture is turned into TL culture [6]. Cultural differences along with differences in food will affect the translation results. Moreover, a translated literary piece is not the same as literature written in the original citizens' language, because a translated work is no longer a narrative conveyed in the nation's own linguistic values, but rather in the translator's language [21]. Moreover, an approximated translation of a term comprising the SL culture into a word containing the TL culture is known as Cultural Equivalent [6].

SL : he was desperate

TL : kini ia nekat 
There are lexical and morphological problems included in the problem of lexical ambiguity (polysemy) and time reference. Polysemy is a form of language (words, phrases, etc.) that have more than one meaning. Moreover, When translating particular works such as fiction, translators must copy the entire plot, context, setting, and surroundings into another language [14]. In the sentence "he was desperate" which is translated into "kini ia nekat" there are adjustments in this sentence. The word "desperate" has more than one meaning. Therefore the context of what is happening or what is being discussed is very important to note. The meaning of more than one occurs because there are several concepts in the meaning of a word. In addition, in SL the sentence format is past tense, while in TL it tends to the present. This is closely related to the difference in sentence structure between SL and TL in English, there are differences in verbs that depend on the time of occurrence and can be classified as regular or irregular verbs, and in Indonesian, in the use of verbs, there is no difference in the time of occurrence, whether it is for the past, present, or at any time. The verb used will remain the same.

\section{SL : Out of the frying-pan into the fire}

\section{TL $\quad$ : Lepas dari mulut harimau jatuh ke mulut buaya}

Then, there are cultural phenomena in translation that are found. Cultural problems in translation arise as a result of the differences between the two languages in expressing identity and lifestyle. Translators will find it difficult to translate abstract or concrete concepts in the source language/culture (SL/C) which are completely unknown in the target language/culture $(\mathrm{TL} / \mathrm{C})$. There is an idiom from SL. Idiomatic translation that tends to alter the SL's meaning environment by favoring TL idioms and colloquialisms that do not exist in the SL [6]. "Out of the frying-pan into the fire" that is translated into an idiom from TL "Lepas dari mulut harimau jatuh ke mulut buaya". Satisha [14] stated the proper translation of proverbs and idioms is another linguistic challenge. Based on the background, the idioms created are certainly different, maybe in SL people often fry something with a frying pan. The geographical background where TL is used is an archipelagic country that has a lot of tropical forests. As is well known, in the forest there are often wild beasts. These background things are likely to form an idiom that exists in each society. Dabaghi and Bagheri [22] stated the translator must identify and understand the source text's idioms and other figures of speech. In addition, an idiom cannot be translated literally without additional notes. It is a good thing if idioms in one language have equivalents that are under idioms in other languages so that the messages contained can be conveyed even though they are delivered with different idioms.
SL : A box without hinges, key, or lid,

Yet golden treasure inside is hid,

TL : Ada kotak tanpa engsel, tanpa kunci atau penutup,

Tapi di dalamnya berisi emas yang hidup.

The next is a riddle from the book. The first line is "A box without hinges, key, or lid," that is translated into "Ada kotak tanpa engsel, tanpa kunci atau penutup,". When it comes to novels and literary works, translation is all about conveying emotions, feelings, and accurately understanding words with numerous meanings so that fiction goes smoothly Satisha [14]. In this line, the translation and the source language are very suitable. There is an adjustment between SL and TL here, namely the collocation of "a box" is adapted to "ada kotak". The equivalence of the description between the two expressions is still acceptable. In a translation, the description must sometimes be assessed concerning its function [6]. However, in the next line "Yet golden treasure inside is hid," which is translated to "Tapi di dalamnya berisi emas yang hidup.", there is an adjustment. The meaning of the word "hid" is lost, while "hidup" replaces it. The two things are different, and this is most likely related to the sound from the end of the first line in TL. Newmark [6] stated "Free translation is a lengthier paraphrase of the original text that is referred to as an 'intralingual translation.' It is usually pompous and lengthy, and it is not a translation at all, and Paraphrase is a way of explaining or reinforcing the meaning of a passage of text."

The last data is a stanza from a song in the book. There are many songs there, but the researcher takes a stanza for the example. Here is the stanza:

SL : Burn, burn tree and fern!

Shrived and scorch!

A fizzling torch

To light the night for our delight,

Ya hey!

TL : Menyala, menyalalah pohon dan pakis!

Sementara Kurcaci meliuk dan meringis!

Api menyala berkobar,

Seperti sinar obor memancar!

Malam pun menjadi terang,

Dan hati kita pun girang! 


\section{Ya, hei!}

There are many adjustments in this stanza. Since ancient times, literary language has been given a distinct character [23]. Paraphrasing, maintaining the equivalent description, and maintaining the beauty of rhyme can be found in this stanza. There are componential analysis and compensation phenomena here. The separation of a lexical unit into its sense components is known as 'componential analysis', and it is typically done in oneto-two, -three, or -four translations [6]. When translators embark on the arduous work of translating folk music, mythical plays, and folk stories, they encounter a number of cultural barriers [14]. In this stanza, the first and the second line in SL are like blending in the first to third lines in TL while the third line in SL changes shape in the fourth line in TL even though it still has the same meaning. Then, the fourth line in SL changes to two lines in TL, namely the fifth and sixth lines. The fifth line in SL becomes the seventh line in TL.

To understand idioms, jargon, metaphors, and slangs from various languages, considerable linguistic expertise is required. [14]. There are also the adjustments that give rise to "Sementara Kurcaci meliuk dan meringis!" and "Api menyala berkobar" in the TL, for the sentences, do not exist in the SL stanza, but if the readers look at the context, the lines are still appropriate. This seems to be closely related to the rhymes in the stanza so that the element of the beauty of the wording in a song remains even though it makes many adjustments to the words and equivalences. All writings must be understood in context, and literary works excel at enhancing meaning through the use of extratextual reference [24]. Besides, translator must be able to discover an acceptable equivalent for the source language's message or information [25]. Furthermore, by focusing on their creativity, translators can offer a detailed explanation of the SL's unknown idea in TL [26].

\section{CONCLUSION}

This research analyzed the linguistics and cultural problems of translations found in the novel entitled "The Hobbit or There and Back Again" which is translated into the Indonesian version entitled "Hobit atau Pergi dan Kembali". The findings show that there are many adjustments as well as the phenomenon of equivalence between the two languages. The meaning that the author wants to convey, the structure of words and sentences, point of view, rhyme, wordplay, context, socio-cultural, and geographical conditions are things that affect the form of translation presented. These findings suggest that the use of good approaches, methods, and procedures will result in an acceptable translation and convey the meaning of the SL without having to sacrifice many things.

\section{AUTHORS' CONTRIBUTIONS}

TRI was involved in the research planning and design, as well as data collecting and analysis. FM and $\mathrm{N}$ contributed to the research design, data analysis, and text structure.

\section{ACKNOWLEDGMENTS}

The researchers would like to thank the experts who assisted with the instrument validation section. The researcher also would like to thank J.R.R. Tolkien as the author of "The Hobbit or There and Back Again" and A. Adiwiyoto as the translator of the novel into the Indonesian language version entitled "Hobit atau Pergi dan Kembali." 


\section{REFERENCES}

[1] F. Mu'in, Sociolinguistics A Language Study in Sociocultural Perspectives, Jurusan Pendidikan Bahasa dan Seni. Fakultas Keguruan dan Ilmu Pendidikan, 2019.

[2] A. Ece, The Trajectory of Literary Translation: From Interpretation to (Re)writing and a New Life, Synergies Turquie no. 8, 2015, pp. 145-155.

[3] V. Kononenko, Linguistic and Cultural Studies: The Quest for New Ideas, in: Proceedings of Journal of Vasyl Stefanyk Precarpathian National University, vol.1, no. 4, 2014, pp. 35-45.

[4] R. Andriyanie, F. Hendro Firmawan, R. Tri Wahyu, Analysis of Translation Techniques in Translating Cultural Words into Indonesian in the Novel "Eat, Pray, Love" By Elizabeth Gilbert, in: Proceedings of Jurnal Ilmiah Sastra. Vol. 4, 2016, No. 1.

[5] K. Ming-Mu Kuo, L. Cheng-Chieh, Linguistics across Cultures: The Impact of Culture on Second Language Learning, in: Proceedings of Journal of Foreign Language Instruction. Retrieved from https://files.eric.ed.gov/fulltext/ED496079.pdf

[6] P. Newmark, A Textbook of Translation, London, Prentice-Hall International Ltd. 1988.

[7] M. Zhang, Some Thoughts on the Influence of Culture on Translation in Literary Translation, in: Proceedings of Advances in Computer Science Research, vol. 83, 2018.

[8] H. Hussain, S. Syed, Translating a Literary Text: Enigma or Enterprise, in: Proceedings of International Journal of English Language \& Translation Studies, 2017, pp.75-80. ISSN: 23085460 .

[9] M. Madkour, Linguistic Levels of Translation: A Generic Exploration of Translation Difficulties in Literary Textual Corpus, in: Proceedings of International Journal of Applied Linguistics \& English Literature, vol. 5, no. 6, 2016. ISSN 22003592 (Print), ISSN 2200-3452 (Online)

[10] Z. Cheng, The Role of Literary Theory in Literary Translation, in: Proceedings of Studies in Linguistics and Literature, vol. 4, no. 4, 2020. ISSN 2573-6434 (Print) ISSN 2573-6426 (Online).

[11] G. E. Putrawan, Foreignization and Domestication of Indonesian Cultural Terms in The Novel Gadis Pantai Translated Into English, in: Proceedings of Lingua Cultura, vol. 12, no. 3, 2018, pp. 309-315.

[12] K. Kazakova, A. Tamara, Strategies of Literary Translation, in: Proceedings of Journal of Siberian Federal University. Humanities \& Social Sciences, v o 1.12 , no. 8,2015 , pp. 2842-2847.

[13]F. Mu'in, Ekokritisisme: Kajian Ekologis dalam Sastra, in: Proceedings of Literature and Nation
Character Building, 2013. ISBN: 602-7762-18-7 ISBN13: 978-602-7762-18-3

[14] M. Satisha, Linguistic and Cultural Challenges Faced by Translators, in: Proceedings of International Journal of Psychosocial Rehabilitation, vol. 24, issue 02, 2020. ISSN: 1475-7192

[15] M. Albakry, Linguistic and Cultural Issues in Literary Translation, in: Proceedings of Translation Journal, vol. 8, no. 3, 2004.

[16] R. C. Apostolatua, A. Ionel, Linguistic and Cultural Issues in Translating Negation in Literary Texts: A Case Study, in: Mourning Becomes Electra, by Eugene O'Neill, Proceeding sof Social and Behavioral Sciences, vol. 63, 2012 , pp. $63-68$.

[17] J. W. Creswell, J. David-Creswel, Research Design. Los Angeles: SAGE, 2018.

[18] H. Chen, Research on Literary Translation Capability and the Construction of Training Mode, in: Proceedings of International Conference on Education Technology and Economic Management, Atlantis Press, 2015.

[19] J. R. R. Tolkien, The Hobbit or There and Back Again, London: HarperCollinsPublishers, 2006.

[20] J. R. R. Tolkien, Hobbit atau Pergi dan Kembali. Translated by A. Adiwiyoto, Jakarta: PT Gramedia Pustaka Utama, 2018.

[21] P. Plyth, S. Parl, P. Clatown, Craham. Translation affects literary and cultural systems: how to observe the features of translation?, Regular Issue Article. 2020. ISSN 2768-0193 DOI:10.51708/apptrans.v14n1.1141.

[22] A. Dabaghi, M. Bagheri, The Issue of Translating Culture: A Literary Case in Focus, in: Proceedings of Theory and Practice in Language Studies, vol. 2, no. 1, 2012, pp. 183-186.

[23] H. S. Ghazala, Literary Translation from a Stylistic Perspective, in: Proceedings of Studies in English Language Teaching, vol. 3, no. 2, 2015. ISSN 2372-9740 (Print) ISSN 2329-311X (Online)

[24] D. Katan, Translating the "Literary" in Literary Translation in Practice, in: Proceedings of Lingue e Linguaggi. Lingue Linguaggi, vol. 14, 2015, pp. 7-29. ISSN 2239- 0367, e-ISSN 2239-0359.

[25] H. Hilman, H. Evert, The Translation of Indonesian Cultural Lexicons in The Novel Saman, in: Proceedings of Jurnal Lingua Cultura, vol. 9, no. 1, 2015.

[26] L. Tiwiyanti, A. B. Retnomurti, Loss and Gain in Translation of Culture-Specific Items in Ahmad Tohari's Lintang Kemukus: A Semantic Study, in: Proceedings of Lingua Cultura, vol.11, no.1, 2017, pp. $1-6$. 